Chapman University

Chapman University Digital Commons

Education Faculty Articles and Research

College of Educational Studies

6-19-2017

\title{
“That's Why I Say Stay in School”: Black Mothers' Parental Involvement, Cultural Wealth, and Exclusion in Their Son's Schooling
}

Quaylan Allen

Chapman University, qallen@chapman.edu

Kimberly A. White-Smith

Chapman University, kwsmith@chapman.edu

Follow this and additional works at: http://digitalcommons.chapman.edu/education_articles

Part of the African American Studies Commons, Educational Assessment, Evaluation, and Research Commons, Educational Sociology Commons, Family, Life Course, and Society Commons, Other Education Commons, Other Sociology Commons, Place and Environment Commons, Quantitative, Qualitative, Comparative, and Historical Methodologies Commons, Race and

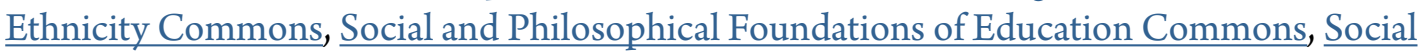
Psychology and Interaction Commons, and the Sociology of Culture Commons

\section{Recommended Citation}

Allen, Q. \& White-Smith, K. (2017). “That's why I say stay in school”: Black mothers' parental involvement, cultural wealth, and exclusion in their son's schooling. Urban Education, 0042085917714516. https://doi.org/10.1177/0042085917714516

This Article is brought to you for free and open access by the College of Educational Studies at Chapman University Digital Commons. It has been accepted for inclusion in Education Faculty Articles and Research by an authorized administrator of Chapman University Digital Commons. For more

information, please contact laughtin@chapman.edu. 


\section{"That's Why I Say Stay in School": Black Mothers' Parental Involvement, Cultural Wealth, and Exclusion in Their Son's Schooling}

\section{Comments}

This is a pre-copy-editing, author-produced PDF of an article accepted for publication in Urban Education in 2017 following peer review. The definitive publisher-authenticated version is available online at DOI:10.1177/0042085917714516.

\section{Copyright}

The authors 


\title{
"That's Why I Say Stay in School": Black Mothers' Parental Involvement, Cultural Wealth, and Exclusion in Their Son's Schooling
}

\author{
Quaylan Allen ${ }^{1}$ and \\ Kimberly White-Smith ${ }^{2}$
}

\begin{abstract}
This study examines parental involvement practices, the cultural wealth, and school experiences of poor and working-class mothers of Black boys. Drawing upon data from an ethnographic study, we examine qualitative interviews with four Black mothers. Using critical race theory and cultural wealth frameworks, we explore the mothers' approaches to supporting their sons' education. We also describe how the mothers and their sons experienced exclusion from the school, and how this exclusion limited the mothers' involvement. We highlight their agency in making use of particular forms of cultural wealth in responding to the school's failure of their sons.
\end{abstract}

\section{Keywords}

parent participation, urban education, African American students, high school, critical race theory, Black males, discipline policies

\section{Introduction}

This study examines the parental involvement practices, cultural wealth, and school exclusion of poor and working-class mothers of Black boys. Parents

${ }^{1}$ Chapman University, Orange, CA, USA

¿University of La Verne, CA, USA

Corresponding Author:

Quaylan Allen, College of Educational Studies, Chapman University, One University Drive, Orange, CA 92866, USA.

Email: qallen@chapman.edu 
of Black boys regularly observe the many structural factors that contribute to the uneven school outcomes for their sons. Black boys are regularly placed into lower ability and remedial courses, or are over-diagnosed with subjective disabilities that lead to their over-representation in special education programs (Artiles, 2011; Sullivan \& Bal, 2013). The intersection of hegemonic ontologies of Black masculine deviancy and so-called "colorblind" school discipline policies contribute to the excessive surveillance and disproportionate discipline of Black boys (Skiba et al., 2014). Black males who attend segregated schools are often subject to even greater surveillance and discipline as these schools are more likely to increase police presence on campus or outsource their disciplinary functions to local police forces (Welch \& Payne, 2010). This subjects Black boys (as well as Black girls, queer and transgender students) to unnecessary contact with the criminal justice system and contributes to what is well known as the schoolto-prison pipeline (Losen \& Martinez, 2013; Noguera, 2003). While there is growing evidence of how Black males succeed in school despite these conditions (Harper, 2012; McGee \& Martin, 2011; Milner, 2008), it is clear that certain school policies and practices limit Black students' opportunity to learn and contribute to inequitable social stratification.

Black parents not only observe these outcomes for their sons but also encounter the school's structural and cultural barriers in comparable ways as their children. Within a school system that privileges White middle-class norms, aesthetics, and parenting styles, the parental involvement practices of Black parents are often pathologized. Educators tend to assume Black parents are uninvolved or do not care about their children's education (Cooper, 2005; Fine, 1993). When educators interact with Black parents, the parents' behaviors are regularly misinterpreted as confrontational and uninformed (Diamond \& Gomez, 2004; Lareau \& Horvat, 1999). As a result, many Black parents describe schools as a site where they feel unwelcomed and excluded (Abrams \& Gibbs, 2002; Noguera, 2001). There is an emerging body of literature that is problematizing deficit discourses about Black parenting by examining the counterstories of Black parents and their experiences within the school (Cooper, 2009; Grantham \& Henfield, 2011; Howard \& Reynolds, 2008). This study seeks to contribute to this literature by examining the counterstories of four Black poor and working-class mothers of Black male students. In this article, we describe the different parental involvement approaches and cultural wealth of the mothers, their encounters with the exclusionary practices of school personnel and administration, and their agency in drawing upon particular forms of cultural wealth in response to their exclusion. 


\section{Literature Review}

Black parents have a well-documented history of involvement in their children's education and engage in a range of parental involvement practices that support the well-being and overall success of their children. Education scholars writing on the history of Black schooling describe how Black parents sending their children to 19th- and 20th-century segregated schools invested in education as a means of political and economic self-determination and racial uplift (Anderson, 1988; Fairclough, 2007; Walker, 1993). Black parents in these segregated communities supported their children's education in ways similar to Black parents today. Research on the current state of Black schooling describes some of the school-based parental involvement practices of Black families, which includes volunteerism in the classroom, participating in parent groups and school governance, and investing financial resources to support educational activities (Abel, 2012; Clark, 1983; Noël, 2014; Posey-Maddox, 2012; Thompson, 2003).

These types of school-based involvement practices, in addition to homebased involvement such as monitoring homework, can contribute to academic success (Jeynes, 2007; Pomerantz, Elizabeth, \& Scott, 2007). However, these types of involvement practices tend to be school-centric, and prioritize the goals of the school over the needs of the community (Adelman, 1992; Baquedano-Lopez, Alexander, \& Hernandez, 2013; Lawson, 2003). These approaches to parental involvement also reflect the economic privilege of middle-class families, and not all Black families will be able to engage in such school or home-based activities. For example, the involvement of many poor and working-class Black parents is shaped by time poverty. Balancing multiple and inflexible work schedules, and the cost of child care, limits many parents' ability to participate during school day activities or monitor their children's homework at night (Cooper, 2009; Lareau, 2003).

High school exacerbates these challenges as its structure and form makes school-based involvement more difficult than elementary schools, and also because some parents might perceive the academic content to be too challenging for them to provide adequate academic assistance (Eccles \& Harold, 1993; Green, Walker, Hoover-Dempsey, \& Sandler, 2007). Because school personnel often consider a parent's school presence and homework supervision as indicators of good parenting (Lipman, 1997; Shumow \& Harris, 2000), many Black poor and working-class parents who cannot engage in school-based activities are assumed to be uncaring and absentee, and are positioned through school discourses as unsupportive of the school's norms and functions (Cooper, 2005; Diamond \& Gomez, 2004; Fine, 1993). Thus, schoolbased parental involvement and home-based involvement such as monitoring homework become normalized forms of parental involvement and other forms of educational support provided by Black families are ignored. 
When Black parents are able to access the school, they are often met with rejection and exclusion. Teachers, who are predominantly White, middleclass, and female (Coopersmith, 2009), are more likely to value the parenting styles and cultural capital of White, middle-class parents, and pathologize the parenting styles of Black parents (Abrams \& Gibbs, 2002; McGrady \& Reynolds, 2013; Reay, 1998; Toldson \& Lemmons, 2013). School personnel regularly misinterpreted the behaviors of Black parents as confrontational and uninformed, and tend to dismiss the critiques of Black parents (Diamond \& Gomez, 2004; Lareau \& Horvat, 1999). Black parents are also excluded from White-dominated parent groups and other organizing bodies (Howard \& Reynolds, 2008; McGrath \& Kuriloff, 1999; Posey-Maddox, 2012). As a result, many Black parents describe schools as a site where they feel unwelcome and excluded (Abrams \& Gibbs, 2002; Noguera, 2001), a reason that causes some Black parents to disengage (Hoover-Dempsey et al., 2005).

By relying on narrow understandings of parental involvement, schools not only position Black working-class families as deficient, but also ignore other forms of non-school-based parental involvement that Black parents engage in support of their children's education (Abrams \& Gibbs, 2002; Cooper, 2009; Grantham \& Henfield, 2011). For instance, Black parents manage their children's education by providing proper care in the home (food, shelter, etc.), maintaining high academic expectations, or involving their children in community or church-based educational and leadership activities (Clark, 1990; Gutman \& McLoyd, 2000; Williams \& Sánchez, 2012). Black parents also prepare their children to navigate a society, and a school system in particular, in which racism is endemic (Crenshaw, Gotanda, Peller, \& Thomas, 1995). They do so by preparing their children to respond to interpersonal and institutional racism by teaching their children positive racial messages and providing them techniques and strategies to resist racial hegemony (Friend, Hunter, \& Fletcher, 2011; Hughes \& Chen, 1997; Vincent, Rollock, Ball, \& Gillborn, 2012).

Furthermore, because schools serve as sites of social reproduction and cultural hegemony, school practices such as segregation, disproportionality in discipline, racialized academic tracking, and school funding inequalities have required Black parents to enact agency in their advocacy and activism on behalf of their children's education. For instance, within the school, Black parents individually advocate for their sons who experience racial microaggressions or are denied opportunities due to educator's biases (Allen, 2013; Howard \& Reynolds, 2008). In addition, Black parents have a long history of organizing with community-based groups to reform school funding, educational access, and discipline practices that directly affect the educational and democratic opportunities for their children (Anderson, 1988; Cooper, 2003; Fuentes, 2012; Oakes, 2008; Shujaa, 1992).

Many of these individual and collective involvement practices of Black parents go unrecognized or are undervalued by school personnel, and popular 
discourse and scholarship on Black parents has historically focused on their deficits as opposed to their assets (Coleman, 1991; Moynihan, 1965; Whitehouse \& Colvin, 2001). More qualitative research is needed to document the agency, cultural capital, and involvement practices of Black families, particularly those in secondary education settings.

\section{Theoretical Framework}

In examining the parental involvement of Black working-class mothers, this study employs critical race theory (CRT) as a theoretical lens, foregrounding the role of race and racism in the school experiences of Black parents (Delgado \& Stefancic, 2001). Scholars using CRT challenge dominant discourses on race and culture and examine the way racism and its intersection with other forms of oppression contribute to how educational policy and practices are used to subordinate certain racial groups (Crenshaw et al., 1995; Solorzano, 1998). CRT also urges its scholars to examine how the interests of privileged groups are preserved and to challenge educational policies, practices, ideologies, and theories that are positioned as commonsense, normal, colorblind, or objective (Lynn \& Dixson, 2013; Milner, 2013). Bourdieu's cultural capital theory, for example, has long been used to explain the way schools privilege White middle-class norms, aesthetics, and acquired knowledge. Bourdieu (1977) describes cultural capital as the knowledge, dispositions, orientations, goods, and credentials that members of dominant groups possess. This might include particular approaches to parenting and school involvement, specific educational and occupational expectations, greater access to personal libraries and personal technologies, or regular visits to museums or other educational vacations (Barone, 2006; Bourdieu, 1990; Dumais, 2002). These forms of capital are often privileged within the context of school and are often used for social and cultural exclusion as many nondominant groups may or may not be able to access or exhibit similar forms of cultural capital.

Scholars employing CRT have critiqued educational practices, discourses, and theories that privilege these types of White middle-class cultural capital that are often used to pathologize the cultural capital of Black families (Yosso, 2006). In other words, Black families are positioned as culturally deficient if they do not exhibit White middle-class cultural capital and aesthetics. Yosso (2006) in particular has critiqued Bourdieu's narrow view of cultural capital that socially constructs the Black family as deficient. In decentering White cultural capital as the norm, Yosso provides an expanded view of cultural capital to include the skills, knowledge, connections, and abilities used by communities of color to fight discrimination and oppression. This could include aspirational capital, which is the ability to maintain hopes despite racial injustice or linguistic capital, which is the ability to master more than one language or communication style. 
Other forms of cultural capital outlined by Yosso include familial capital, which includes the knowledge families transmit to each other and the kinships that are developed, or social capital, which are the networks and community resources that people of color rely upon. Finally, families of color might possess and activate navigational capital, which includes the ability to maneuver through institutions that have historically excluded people of color, and resistant capital, which is the ability to recognize and contest dominant ideologies and exclusionary practices (Yosso, 2006, p. 176). Yosso's explanation not only broadens an understanding of cultural capital, but it also identifies the types of messages, knowledge, skills, and expectations that parents of color transmit to their offspring with the intention of resisting the "reproductive" nature of schools and increasing opportunities for social and occupational mobility. Thus, the current study is informed by CRT in general, and Yosso's work in particular, as we aim to identify the unique cultural wealth of Black parents through the counterstories of Black poor and working-class mothers. In the next section, we review the methodology before presenting the results.

\section{Method}

The findings presented in this article derive from a larger ethnographic study examining the schooling experiences of Black male youth and their families (Allen, 2013, 2015). The study sample, drawn through purposive and snowball sampling methods (Goetz \& LeCompte, 1984), included 10 Black families sending their sons to a racially integrated high school in a large U.S. west coast metropolis. Central High School, ${ }^{1}$ was a racially and economically diverse suburban school. At the time of the study, the student population was 29\% Black, 28\% Asian, 19\% Latino, 11\% White, and 13\% Other, and almost half of the students qualified for a free or reduced-price lunch. ${ }^{2}$

The study included 10 Black male students and their families; six of the families were middle-class and four were poor or working class. Data were collected through field observations, document collection, and semi- and unstructured interviews. Within the school, field observations and unstructured interviews were conducted with students and teachers in classrooms, hallways, cafeterias, teachers' lounge, and sporting events, among other school spaces. The male student participants took part in three separate semistructured interviews that explored their experiences in school and how they made meaning of school opportunity, achievement, and their social position as raced-gendered bodies. The parents and teachers also were each interviewed formally one time. Interviews with the parents concerned their perspective of their son's educational history, their own involvement with their son's schooling, and their views on race and manhood. The students were asked to nominate a teacher to be interviewed on their behalf and these interviews focused on the teachers' perceptions of the Black male 
student participants' schooling experiences. Taken together, the interviews became multivocal interpretations on the same phenomenon (Tobin, $\mathrm{Wu}, \&$ Davidson, 1989), and were an important source for discovering meaning behind the actions and behaviors of participants.

The data presented in this article comes from the qualitative interviews with the four poor and working-class parent participants, focusing on the counter narratives of these mothers, as well as their interpretation of their sons' schooling and their own parental involvement practices. All interviews and observations were transcribed, coded, and analyzed using Erickson's (1986) qualitative interpretive approach. This included using Atlas.ti qualitative research software to code and manage the data. The data were bracketed into elements that were analyzed independently for noncontextual meaning (Denzin, 1989). After coding and bracketing, the data corpus was again reviewed thoroughly to search for key linkages among the different forms of data, with a goal of developing an initial set of empirically grounded assertions. The data corpus was then reviewed again as a means to test initial assertions in light of confirming and disconfirming evidence. Assertions were then organized into major themes and subthemes, and the data were reconstructed and contextualized within the historical moment in which they were produced. Finally, member-checking was employed by providing participants with manuscript copies and asking for feedback on generated final themes (Lincoln \& Guba, 1985).

\section{Participants}

The mothers presented in this article possessed an array of cultural wealth and were involved in their children's lives in varying ways, despite many of the structural barriers they faced (see Table 1). The families can be economically characterized as poor or working class. Each family qualified for a free or reduced-cost lunch program, the mothers had modest educational backgrounds, and only one of the mothers was employed at the time of the study. Each mother was the primary care taker of their young children and often lacked extended family that could assist with child care. Research has shown that the lack of affordable child care, and the associated time poverty, can be significant barriers to the mobility and school involvement of parents (Green et al., 2007; Machen, Wilson, \& Notar, 2005; Newman \& Chin, 2003). As a researcher, the first author was able to observe and document many of the ways these mothers supported their children's education outside of the school, though within the school, the parents were often characterized by schoolteachers through pathologizing discourses as uninvolved, difficult to develop relationships with and enabling of their son's resistance to schooling (Allen, 2015). 


\section{Parental Involvement and the Cultural Wealth of Black Mothers}

The mothers in this study supported their son's education in a range of ways. Some of their involvement would be considered more traditional and were generally recognized within the school. Other involvement practices, and the cultural wealth the mothers drew upon, were less visible to the school but had equal importance in supporting their son's education. In their interviews, the mothers described their school-based involvement, volunteerism, and educational expectations for their children. They also described how they navigated and managed race, and how they racially socialized their sons.

\section{School Involvement and Educational Expectations}

The mothers participated in their sons' schooling in ways that are generally normalized and encouraged by the school. Describing their involvement when their sons were in elementary school, the parents explained how they were able to enter the school, assist in the learning of their children in the classroom, and maintain relationships with teachers. Ms. Dempsey, the mother of Santonio explained, "In elementary school it was a lot more hands on. I had more of a rapport with the teachers, probably because he just was in one class all day and it was easier to have that relationship with them." Similarly, Ms. Hall, the mother of Andre explains her school involvement:

In elementary, I would go up there, volunteer, sit in the classes, go on all the field trips. And junior high I was up there pretty actively, just you know, meeting with his teachers and seeing where Andre was at and seeing what was going on with Andre ... So far as high school, not that much. Elementary school, junior high school, always up there. I have rapport with the counselor at the high school and the secretary I'm always checking on him. But as far as that one on one with the teachers, no, it's not as much as it used to be.

In addition to classroom volunteerism, the mothers attended parent-teacher meetings, attended field trips, and monitored their sons' homework. But as Ms. Dempsey and Ms. Hall allude to, these types of practices were much easier to accomplish at the elementary level. The structure and form of

Table 1. Occupation and Education of Participants.

\begin{tabular}{llll}
\hline Parent alias & Student alias & Mother's occupation & Education \\
\hline Ms. Simmons & Garrett & Unemployed & High school diploma \\
Ms. Dempsey & Santonio & Senior office assistant & Associate's degree \\
Ms. Hall & Andre & Unemployed & Some high school \\
Ms. Powell & Dontay & Unemployed & High school diploma \\
\hline
\end{tabular}


elementary school allowed for easier access, more involvement opportunities, and the ability to develop meaningful relationships with their sons' teachers. In contrast, the structure and form of the high school became a barrier, as the size and bureaucracy of high schools place significant limitations on how parents can monitor their sons schooling in particular ways (Eccles \& Harold, 1993). The mothers' school-based involvement in their sons' high school was then largely limited to their attendance at parent-teacher conferences or supporting their sons' participation in extracurricular activities such as sports.

In addition to volunteerism and school relationship building, the mothers described the cultural wealth they used to support their sons' education. They shared examples of aspirational capital, which was their value of education and the educational expectations they held for their sons. They all desired for their sons to attend college but were also pragmatic in how they explained the value of formal schooling to their children. Linking educational attainment to economic mobility, Ms. Dempsey, who worked for the county, explained to her son how obtaining additional college credits would enable her to earn salary increases. Similarly, Ms. Simmons stressed to her son Garrett the value of a formal education by describing the potential consequences for dropping out:

That's why I say stay in school. And then you can get the nice things. You can
get credit, you can have whatever you want. But if you don't stay in school,
you can still have nice things, but you're going to be hustling, selling dope,
doing stuff that eventually if you get caught you go to jail and so now you don't
have nothing nice. And he [Garrett] says, "well I'm not going to do that.” Then
I say, "well you need to get the grades.” Like if you want to go to college, you
need to have a certain [GPA]! Yeah and if you get in trouble, that's on your
record. That kind of stuff follows you from school to school.

How the parents described their educational aspirations appear to be rooted in their lived experiences as Black working-class parents. They emphasized the benefits of education toward financial mobility and provided pragmatic rationales for formal schooling. School personnel tend to hold generalist deficit views of Black mothers and essentialize Black parents as uncaring of their child's educational attainment (Diamond \& Gomez, 2004; Fine, 1993). The mothers in the present study held high educational aspirations and cared about their sons' educational success. Considering though, the very real economic and racial barriers the families faced, it appears their educational expectations were philosophically pragmatic. They generally viewed the purpose of schooling as a tool for work preparation and economic mobility, and hoped to send their sons to college. They also understood the financial challenges of funding a college education. 


\section{Navigating Race}

Racism, and its intersection with class and gender exploitation, is endemic in American society (Bell, 1992; Crenshaw et al., 1995). In addition to providing for their children as all parents do, Black parents have the additional burden of raising children in a racist society in which they are pathologized and discriminated against. Black parents then must learn to navigate, manage, and resist racial marginalization and prepare their children to do the same (Mandara, 2006; Vincent et al., 2012). These forms of racial capital are the types of cultural wealth and involvement the mothers used in support of their sons education, but are often unrecognized or undervalued by the school.

In her interview, Ms. Powell described her racial capital as well as her navigational capital, which is her ability to maneuver through and manipulate institutions and practices that were designed to exclude Black families (Yosso, 2006). School zoning policies exemplify this type of racial exclusion, as many school boundaries are drawn to exclude poor and communities of color from access to predominantly White schools (Gotham, 2002; SiegelHawley, 2013). Such zoning practices contribute greatly to segregated schools and the property interest of Whiteness to exclude people of color from equitable schooling opportunities (Harris, 1993). Ms. Powell demonstrates her knowledge of and resistance to such school zoning policies by explaining how in order to improve the educational opportunities for her children, she had spent months analyzing school district boundary maps and available housing options and designed a strategy for moving to a neighborhood zoned for a respected and high-performing school district. She reasons stating,

I don't want to just live anywhere. It's really important to give my kids the best opportunity possible. This is a really nice neighborhood. If I had to choose between the biggest and baddest house in the ghetto or a teeny tiny house in the uppity bump whatever, I'll take that teeny tiny house.

She goes on to explain how she was able to secure the house through her management of race through the presentation of self:

So you know, but, but the man who is renting it, even though I don't have section eight, he wants to check out his potential tenants more than anyone I've ever seen. So I have my strategies and so I decided since I have a number of kids, you know, sometimes people are picky about that. So I've got my kids up. The plan was to get up, get dressed, get everybody's hair combed, get your pants real sharp, you know, get the car cleaned out and drive up and I talked to them about how to present themselves and be amenable, don't run around the house and whatever and to let this man see these are my children. And this is 
who will be in your home and so I wanted to be as thorough as possible in this process.

Ms. Powell's strategy here seems to be in response to both the racialized zoning practices of schools as well as the larger stereotypes about single Black mothers with multiple children. Recognizing how a potential renter might view her, Ms. Powell manages race in ways that attempts to dispel any myths about Black single motherhood. In doing so, she seems to experience a form of double-consciousness, recognizing how the White world might see her and responds through a re-presentation of self that allows her to navigate school zoning boundaries and access the desired educational opportunity for her children.

The racial consciousness experienced by Ms. Powell and the ability to respond to racialized events was a form of racial capital the mothers attempted to pass on to their sons. As parents raising Black children in a society in which racism is endemic, Black parents often participate in the racial socialization of their children to prepare them to navigate a racist society (Hughes \& Chen, 1997; Mandara, 2006). The mothers in the present study advised their sons on how to manage the racial microaggressions their sons would encounter. This included both overt and covert forms of discrimination that demean and subjugate Black people (Sue, Capodilupo, \& Holder, 2008). Describing a racialized incident that her son Garrett had at work, Ms. Simmons explains her racial socialization practice:

He came home one day and the lady [he works with] announces over the loud speaker, "come here boy” or something. And I said "okay, Grant.” I said "talk to the lady." And he was like, "what am I going to say to her," and I was said "well, you need to talk to the lady if it really, really bothered you, but if you could deal with it, I mean deal with it." So I said "just tell her nicely, I heard you, I didn't know you were talking about me. My name is Grant.” And so he's never had no problems with her no more. But I said, "those are the things you will go through probably for the rest of your life. Any job you get, you may be chummy-chummy with your boss, other coworkers, but there's always one, two, sometimes a few, that are going to make comments that you don't like." I said "but you have to deal with them in a responsible way, respectful sometimes and sometimes not, but without being belligerent and without cussing them out.”

Black families racially socialize their children in varied ways, with practices ranging between proactive and reactive (Mandara, 2006; Miller, 1999). It appears that Ms. Simmons is proactive in her racial socialization in that she has a direct conversation with her son about the racist encounter, provides him with tools to resolve this issue but also cautions him about future racial microaggressions he might encounter. Similar to other Black families, the parents expected that these types of lessons would be understood 
by their sons and would be drawn upon as their sons navigated other institutional settings such as school (Hughes \& Chen, 1997; Vincent, Rollock, Ball, \& Gillborn, 2013). The possession and activation of racial and navigational capital highlights the cultural wealth and involvement of these Black mothers, and provides valuable insight into the range of ways that Black poor and working-class mothers support their sons' education both in and outside of the school.

\section{"What About Education?" School Exclusionary Practices and Educational Inequality}

Though the parents were supportive of their sons' education, it appears that the structure and form of the high school, as well a deficit discourses about Black families, placed limitations on how these mothers could be involved. As previously described, the mothers were more involved at the elementary years and talked about the difficulties of being able to monitor their sons' education at the high school level. Research on parental involvement practices generally point to the size and bureaucracy of high schools as contributing factors to decreased parental involvement (Eccles \& Harold, 1993). For the mothers, the structure of high school made it more difficult to navigate institutional bureaucracy and feel connected to the school. Thus, they were critical of the limited access they had to the school, and its ability to provide an equitable experience for their sons. In the interviews, the mothers discussed the different ways school practices and policies excluded them from the school or limited their sons' educational opportunity, and how in some cases were able to use their cultural wealth to resist the school's exclusionary structure.

\section{School Exclusion of Black Mothers}

The parents described difficulties in accessing the high school and its personnel and how they felt ignored, treated differently or made to feel unwelcomed despite their attempts to make themselves available to the school. The mothers talked about being proactive in reaching out to teachers in support of their sons' education and the frustrations they experienced when teachers were unresponsive. Ms. Dempsey describes her frustration with trying to communicate with her son's teacher regarding his grades:

And then I've requested several times, if you have a concern, because his grades are not the greatest right now, if you have a concern or if there's anything going wrong that I should know please communicate with me. This is my name, this is my phone number. I give them everything. First day of the term I send everybody a mass email and let them know who I am. And I won't 
hear anything until I email them and say okay, I'm looking at [the online grade system] and I see that he has a D and it says he's missing an assignment. Why haven't you contacted me and let me know, you know? I would send emails and I would try to talk to her and she would never return my calls. She failed him last year and he had been saying "I turned in my work, there was no reason for her to fail me.” And it was only this year that they sent, like a restructured report card to me that said a mistake was made. And she didn't even apologize to him. There was no apology. It was just like "oops, there was a mistake and now it's fixed.” But this was after we browbeat him, punished him for having this bad grade and lying to us and he actually did the work.

Ms. Dempsey's frustration appears to stem not only from the lack of responsiveness from her son's teacher but also the school's lack of accountability for its own failure. According to Ms. Dempsey, her inability to access the teacher regarding her son's missing assignments contributed to his failing the class and his subsequent punishment from his mother. However, when the school failed, there was no consequence for its actions, nor was their redress for the students it failed. In other words, accountability for Black male educational equality is not distributed equally among Black families and the school.

Ms. Dempsey's counternarrative demonstrates the challenges many Black parents experience in their children's education. Poor and unresponsive relationships with teachers contribute to the way Black parents and their children are excluded from academic opportunities and important educational information (Howard \& Reynolds, 2008; Williams \& Sánchez, 2012), even when parents access the school through its designated communication tools (i.e., email). From the perspective of the school, the failure of Ms. Dempsey's son might be interpreted as a colorblind or racially neutral but unfortunate event; however, the outcome not only contributes to pathologizing positioning discourses of Black male academic ability but also ignores the school's role in the systemic failure of Black boys.

More pointedly, the mothers explained the role race played in their and their sons' interactions with teachers. For instance, the mothers felt that teachers were often intimidated by them when they asked to enter the classroom to help and observe, and as mothers of Black boys, they were keen to how racialized and deficit discourses influenced their and their sons' interactions with teachers. Ms. Hall shares a conversation she had with one of her son's teachers:

I do remember one teacher telling me, this was at-it probably would have been the ninth grade-that some times she has a hard time helping African American students because of the way that they present themselves and so that, you know, I had a problem with that. She was saying that she doesn't take "them” serious because they don't seem like they are serious about school. And 
she puts her effort towards "those" students and to me "those" students meant the white students and so that kind of bothered me

Ms. Simmons also spoke to the inequitable interactions Black boys have with their teachers explaining that it's

\begin{abstract}
“Because they're black. You basically get stereotyped. And so even if say, for example he was one of those kids that wore dreads, he's automatically [stereotyped]. But that could be like a straight-A student, but because they get stereotyped, they get treated different."
\end{abstract}

There is substantial evidence that teachers, who are predominantly White and female, often draw upon racial stereotypes and pathologize Black parents and students as intimidating, aggressive, and culturally deficient (Cooper, 2005; Ferguson, 2005; Howard, Flennaugh, \& Terryr, 2012). These attitudes greatly influence the interactions between Black families and teachers by reducing Black boys' opportunity to learn and limiting Black parents' ability to access the school and support their sons' education.

When the mothers did have the opportunity to access the school, they felt their presence on campus was inconsequential. For example, the mothers attended school events such as parent-teacher conferences and Back to School nights, but Ms. Powell explains how she generally feels unwelcome and excluded from the adult networks in the school:

I've been to the [back to] school night. It's funny like I don't know, I don't feel included. I don't know how to explain it. You're not really welcomed in. There's nothing there for you to do. I've been on the campus a few times and you're ignored. It's like, "Hi, how are you doing?” And then after that it's like "Whoa, what do you want here? Go!" What do you do? And then I tried to join the booster club and that's a little clique of parents. That's not my cup of tea, you know? And the thing with the clique is that they are not working, in my opinion, to accomplish anything great for those kids. It's their personal parent cliques to make themselves more important.

Ms. Powell's feeling of exclusion is similar to other Black parents who experience avoidance and marginalization by teachers and predominantly White parent groups (De Gaetano, 2007; McGrath \& Kuriloff, 1999), experiences that contribute to why some Black parents disengage from the school (Lightfoot, 2004). These experiences of exclusion were the impetus for the creation of the African American PTA at Central High. This PTA was well attended by Black parents, including the mothers in this study, though the African American PTA was not considered a central organization and did not yield the same power as the general PTA. 


\section{School Failure and Educational Inequality}

It appears that in the absence of opportunities to be proactively involved at the high school (e.g., volunteering, teacher communication, etc.), the mothers' involvement with the school was often reactive, in that accessing the school was often due to them responding to the ways school policies and practices denied their sons educational opportunity. In Ms. Dempsey's case, she gets access to the school but in response to a school policy that failed to support her son's learning:

I had better expectations for Glenpark School District. Now I know the responsibility, a great part lies on the child. That's his education and he has to want it and he has to know how important it is. But I think the school is also responsible for encouraging that and nurturing that. I had his counselor this year. When I went in I was upset at his grades and I spoke with him, "well, why are you, you know, encouraging him to get involved in all these things when his grades are not so great?” Well, in all honesty, what she told me was that they are going to pass him to the next grade. That's just the standard of Glenpark School District. So it doesn't matter what he does. He's still going to go to the next grade. I'm like, "that's not right though." And she's like, "well it's part of No Child Left Behind" and I'm like "well what about education?" You know?

Ms. Dempsey's narrative points out how school policies can fail Black males. At the time of this study, public schools were operating under the No Child Left Behind Act of 2001, a law that aimed to increase accountability among schools and provided financial incentives for schools to increase their graduation rates. Students who experience grade retention are more likely to drop out, so to increase graduation rates, many school districts relaxed their grade retention policies (Newman \& Chin, 2003; Wakefield, 2012). This ensures that no child is left behind but it also means students, like Ms. Dempsey's son, could graduate with a substandard educational experience. Ms. Dempsey's advocacy for her son's schooling is notable as she attempts to mitigate a moment of school exclusion. However, these are the types of encounters that shape the campus climate and school-based involvement for the mothers in the high school.

Nevertheless, there were moments when the mothers responded to school exclusionary practices in ways similar to other Black parents (Abrams \& Gibbs, 2002; Lareau \& Horvat, 1999), and were able to use their cultural wealth to create moments of inclusion for their sons. Ms. Powell's narrative, in particular, provides a description of the disciplinary process from the perspective of a parent and the cultural capital used to navigate this process. Ms. Powell's son, Dontay, had been put up for expulsion during his sophomore year, and in her interview, she urged Black families to learn about their rights as parents and hold their schools accountable in following their 
own disciplinary procedures. She described her experience with Central High school's expulsion process and critiqued the school's failure to provide families with required notifications and access to student records prior to an expulsion hearing. She continued with her description of the disciplinary hearing and called into question the legitimacy of due process in the expulsion procedure:

The other thing is that when you go to the hearing, they already have their packet ready. Exhibit A through Z. They have letters from all the teachers, they have grades, they have every single thing that has been in that child's folder. Anything that they can find. So you don't even have enough time to look through all of the exhibits. So they say "you see by Exhibit C or D and so therefore this is what we're going to do.” And so like when I went up with my son, one, I feel that a parent should be given that exhibit packet five days prior to the hearing so that you can go through that packet and you can see what they have against your child and you can build your case so you can meet them halfway. But they don't do that. They come in with the packet, the whole thing ready to go and all they do is just run you through it and so you don't have any time.

Ms. Powell's critique points to a larger dilemma of many school disciplinary practices in that Black males, who are disproportionally referred to school discipline (Skiba et al., 2014), are often denied due process and the ability to present evidence and support for their own defense. Just as Ms. Powell explains, the school district had already built a case to prove her son was guilty and deserving of expulsion without allowing Ms. Powell and her son their rights that are protected under the 14th amendment.

Finally, Ms. Powell concludes by describing how she disrupted the expulsion process by drawing upon her navigational and social capital to produce a moment of inclusion for her son:

So what I did was I went with my son, and a really good friend of mine who has known my kids since birth. She's an engineer and so she's got that kind of thinking. That's one and two, I didn't let them rush me. They don't put a time on the hearing. They schedule the hearing for an hour. Who says it's supposed to last an hour? So his hearing was four hours and I sat there and read every exhibit. You know what I'm saying? And then I thought it through, I made my notes, you know and then I consulted with my friend and she had done hers [notes] and I went back and said "You're wrong." And you know what? They could not expel him and not only that, they had to rescind the suspension. They had to reinstate my son in school.

Unlike other research explaining that parental involvement decreases when children are punished for disruptive behavior (Parsons, 2002), the mothers in this study increased their involvement when responding to school discipline. In this case, Ms. Powell refuses to acquiesce to the tidal waves of 
commonsense knowledge being used to justify the removal of her son from school, and activates her considerable cultural wealth in circumventing the expulsion hearing process by creating the space and time needed for her and her friend to build a case in defense of her son. In addition, in recognizing how she might be misinterpreted or dismissed by school officials during the hearing as a working-class single Black mother, she activates her social capital by inviting an engineer friend of hers to provide, either real or imaginary, middle-class status, cultural capital, and support needed to assert her case. Ms. Powell's activation of her cultural wealth created a moment of inclusion for her son that kept him enrolled in his school but it was clear the way race, gender, and class intersected through the types of systemic barriers these mothers faced in supporting their sons' education.

\section{Conclusion and Implications}

Though research on parental involvement has generally characterized Black parents as uncaring or uninvolved (Cooper, 2005; Diamond \& Gomez, 2004; Fine, 1993), in the current study, this characterization does not appear to be entirely true as the mothers used their cultural wealth to support their sons' education in different ways. However, it seems that race, class, and gender intersect with the structure and form of the school in ways that inform how these Black mothers were able to access the high school and support their sons in particular ways. At the elementary level, the mothers described having more opportunities to proactively support their sons' education, communicate with teachers, and participate in ways that are recognized by the school (e.g., volunteerism).

At the secondary level, the structure and form of the school changes, and the bureaucratic functions of the school create more barriers to entry for parents, limiting parents' ability to be involved in the school. The mothers' experiences highlight some of these barriers but also how they met rejection and exclusion even when attempting to utilize the school's recommended communication tools or participate in parent events. When they were able to gain access to the school, it was often in response to the failure of the school in providing an equitable education for their sons. It appears then that the high school placed particular limits on the school involvement practices of these Black mothers by reducing parental involvement to monitoring homework or general surveillance of their children outside the school (Adelman, 1992; Lawson, 2003). This estranges parents from any power within the school and limits their ability to proactively support and advocate for their children by institutionalizing parental deference as the norm.

Furthermore, race, class, and gender intersect with school structure in ways that inform the school-centric involvement of Black working-class mothers, and how they experienced exclusion from the school. This study corroborates previous research on Black working-class parents and the 
barriers they face in secondary schools. Like other poor and working-class parents, time, poverty, and limited access to affordable child care were barriers to school-centric involvement (Green et al., 2007; Machen et al., 2005; Newman \& Chin, 2003). Within the school, the mothers were often pathologized through racialized school discourses as uncaring or uninvolved, and experienced exclusion from the school's central organizing groups (McGrath \& Kuriloff, 1999; Posey-Maddox, 2012). Their critiques of the school's failure were largely ignored and they described the school as a site where they were unwelcomed (Abrams \& Gibbs, 2002; Diamond \& Gomez, 2004; Lareau \& Horvat, 1999).

What this study contributes to the research literature are the counterstories and cultural wealth of Black working-class mothers as an anti-deficit approach to gaining deeper insight into how Black parents support their sons' education in ways that are often less understood or ignored by schools. For the mothers in this study, despite the endemic racism they and their children experience in the school and larger society, they held aspirational capital in the form of high but pragmatic educational expectations for their children. They provided care and safety for their children and proactively racially socialized their children through their own racial capital (Friend et al., 2011; Hughes \& Chen, 1997; Williams \& Sánchez, 2012). Furthermore, despite the racial, economic, and school barriers they faced, the mothers enacted agency in using their navigational capital in school choice and advocacy for their sons against the school's failure to provide equitable opportunities (Anderson, 1988; Cooper, 2005; Oakes, Rogers, \& Lipton, 2006).

\section{Implications}

The findings from this study have implications for educators and researchers working with Black parents. The counterstories of the mothers point to the dilemmas that school-centric views of parental involvement create for poor and working-class Black families. To contest the privilege given to White middle-class cultural capital and parenting practices within schools, educators should consider how to better understand and engage their parents of color in the educational process. One way is through a funds of knowledge approach (Gonzalez et al., 1995; Moll \& Gonzalez, 1997). The U.S. Department of Education's Parental Family-School Partnership framework (Mapp \& Kuttner, 2013) suggests that schools seek out the funds of knowledge of their parent communities as part of the development of sustainable family-school partnerships.

A funds of knowledge approach could serve as the start of a process by which schools can learn about the cultural wealth of the communities they work within, the types of involvement strategies and educational supports Black parents provide for their children, and the localized structural barriers 
that limit parents' access to school. This approach calls for more parentcentric practices that empower parents in the school's decision-making process (López, Scribner, \& Mahitivanichcha, 2001) and educators will need to view Black parents as capable collaborators, advocates, and decision makers (Abrams \& Gibbs, 2002; De Gaetano, 2007; Noguera, 2001). In strengthening family-school partnerships and involving local communities in decision-making processes, schools can be held accountable to meeting community needs, can better advocate with their communities around issues of social justice, and can provide better training to in-service professionals (Gonzalez et al., 1995; Khalifa, 2012; López et al., 2001; Siddle Walker, 1996; Warren, 2016). Furthermore, parents are agents in school reform and should continue to organize in school or community-based settings, and collaborate with other educational stakeholders toward school equity. Parent organizations across the country have successfully advocated for their children by educating their communities on local school policies, and using a variety of negotiation and litigation strategies to enact systemic change in their local public schools (Fuentes, 2012; González, 2011; Goss, 2014; Oakes, 2008).

In addition, teacher education programs should continue to prioritize preparing a predominantly White middle-class teaching force for work with culturally diverse populations (Ladson-Billings, 2000; Milner, 2005; Warren, 2015). This could include challenging preservice teachers' conceptions of race, culture, and parental involvement, and adopting asset-based approaches to thinking about and understanding Black males and their families. One such way is by including coursework on culturally relevant parent involvement as a way to prepare future teachers for developing mutually beneficial relationships with culturally and linguistically diverse parent communities (Beneke \& Cheatham, 2016; Ferrara, 2009; Milner, 2013).

Finally, because the current study only examined four Black working-class mothers with sons attending a racially integrated school, the size and context of the study are limitations to the generalizability of the findings. Future research on Black parents should continue to take anti-deficit approaches to examining the cultural wealth and involvement practices of Black families, with a specific focus on the ways in which parents of Black males support and manage the raced and gendered school experiences of their sons attending integrated high schools. This might also include exploring at greater detail the specific types of localized barriers that high schools create for Black families and their school-based involvement.

\section{Declaration of Conflicting Interests}

The author(s) declared no potential conflicts of interest with respect to the research, authorship, and/or publication of this article. 
Funding

The author(s) received no financial support for the research, authorship, and/or publication of this article.

\section{Notes}

1. The names of the school and participants are pseudonyms. Names have been changed to ensure confidentiality.

2. Student demographic data collected from school documents. Citation withheld to maintain school confidentiality.

\section{References}

Abel, Y. (2012). African American fathers' involvement in their children's schoolbased lives. Journal of Negro Education, 8, 162-172.

Abrams, L. S., \& Gibbs, J. T. (2002). Disrupting the logic of home-school relations: Parent involvement strategies and practices of inclusion and exclusion. Urban Education, 37, 384-407.

Adelman, H. S. (1992). Parents and schools: An intervention perspective. Paper presented at the American Psychological Association San Francisco, CA.

Anderson, J. (1988). The education of Blacks in the South: 1860-1935. Chapel Hill: University of North Carolina Press.

Artiles, A. J. (2011). Toward an interdisciplinary understanding of educational equity and difference: The case of the racialization of ability. Educational Researcher, 40, 431-445. doi:10.3102/0013189X11429391

Allen, Q. (2013). "They think minority means lesser than": Black middle-class sons and fathers resisting microaggressions in the school. Urban Education, 48, 171197.

Allen, Q. (2015). Race, culture and agency: Examining the ideologies and practices of U.S. Teachers of black male students. Teaching and Teacher Education, 47, 71-81.

Baquedano-Lopez, P., Alexander, R. A., \& Hernandez, S. J. (2013). Equity issues in parental and community involvement in schools: What teacher educators need to know. Review of Research in Education, 37, 149-182.

Barone, C. (2006). Cultural capital, ambition and the explanation of inequalities in learning outcomes: A comparative analysis. Sociology, 40, 1039-1058. doi:10.1177/0038038506069843

Bell, D. (1992). Faces at the bottom of the well: The permanence of racism. New York, NY: Basic Books.

Beneke, M. R., \& Cheatham, G. A. (2016). Inclusive, democratic family-professional partnerships: (Re)conceptualizing culture and language in teacher preparation. Topics in Early Childhood Special Education, 35, 234-244. doi:10.1177/ 0271121415581611

Bourdieu, P. (1977). Cultural reproduction and social reproduction. In J. Karabel \& A. H. Halsey (Eds.), Power and ideology in education (pp. 487-511). New York, NY: Oxford University Press.

Bourdieu, P. (1990). The logic of practice. Stanford, CA: Stanford University Press. 
Clark, R. M. (1983). Family life and school achievement: Why poor Black children succeed or fail. Chicago, IL: University of Chicago Press.

Clark, R. M. (1990). Why disadvantaged students succeed: What happens outside school is critical. Public Welfare, 48, 17-23.

Coleman, J. S. (1991). Parental involvement in education [microform] (ERIC ed.). Washington, DC: U.S. Department of Education, Office of Educational Research and Improvement, Educational Resources Information Center.

Cooper, C. W. (2003). The detrimental impact of teacher bias: Lessons learned from the standpoint of African American mothers. Teacher Education Quarterly, 30, 101-116.

Cooper, C. W. (2005). School choice and the standpoint of African American mothers: Considering the power of positionality. The Journal of Negro Education, 74, 174-189.

Cooper, C. W. (2009). Parent involvement, African American mothers, and the politics of educational care. Equity \& Excellence in Education, 42, 379-394.

Coopersmith, J. (2009). Characteristics of public, private, and Bureau of Indian Education elementary and secondary school teachers in the United States: Results from the 2007-08 Schools and Staffing Survey (NCES 2009-324). Washington, DC: U.S. Department of Education, National Center for Education Statistics, Institute of Education Sciences.

Crenshaw, K., Gotanda, N., Peller, G., \& Thomas, K. (Eds.). (1995). Critical race theory: The key writings that formed the movement. New York, NY: The New Press.

De Gaetano, Y. (2007). The role of culture in engaging Latino parents' involvement in school. Urban Education, 42, 145-162.

Delgado, R., \& Stefancic, J. (2001). Critical race theory: An introduction. New York: New York University Press.

Denzin, N. K. (1989). Interpretive interactionism. Newbury Park, CA: SAGE.

Diamond, J. B., \& Gomez, K. (2004). African American parents' educational orientations: The importance of social class and parents' perceptions of schools. Education and Urban Society, 36, 383-427.

Dumais, S. A. (2002). Cultural capital, gender, and school success: The role of habitus. Sociology of Education, 75, 44-68.

Eccles, J. S., \& Harold, R. D. (1993). Parent-school involvement during the early adolescent years. Teachers College Record, 94, 568-587.

Erickson, F. (1986). Qualitative methods in research on teaching. In M. C. Wittrock (Ed.), Handbook of research on teaching (3rd ed., pp. 119 - 161). New York: MacMillan

Fairclough, A. (2007). A class of their own: Black teachers in the segregated South. Cambridge, MA: Harvard University Press.

Ferguson, R. (2005). Teachers' perceptions and expectations and the Black-White Test score gap. In O. S. Fashola (Ed.), Educating African American males: Voices from the field (pp. 79-128). Thousand Oaks, CA: Corwin Press.

Ferrara, M. M. (2009). Increasing parent involvement knowledge and strategies at the preservice level: The power in using a systematic professional development approach. Teacher Educator, 44, 268-274. doi:10.1080/08878730903180192

Fine, M. (1993). [Ap]parent involvement: Reflections on parents, power, and urban public schools. Teachers College Record, 94, 682-710. 
Friend, C. A., Hunter, A. G., \& Fletcher, A. C. (2011). Parental racial socialization and the academic achievement of African American children: A culturalecological approach. Journal of African American Studies, 15, 40-57.

Fuentes, E. H. (2012). On the rebound: Critical race praxis and grassroots community organizing for school change. The Urban Review, 44, 628-648. doi:10.1007/ s11256-012-0208-3

Goetz, J. P., \& LeCompte, M. D. (1984). Ethnography and qualitative design in educational research. Orlando, FL: Academic Press.

Gonzalez, N., Moll, L. C., Tenery, M. F., Rivera, A., Rendon, P., Gonzales, R., \& Amanti, C. (1995). Funds of knowledge for teaching in Latino households. Urban Education, 29, 443-470.

González, T. (2011). Restoring justice: Community organizing to transform school discipline policies. UC Davis Journal of Juvenile Law \& Policy, 15

Goss, A. C. (2014). Push back on push out: Parent organizing for school discipline reform (Doctoral dissertation). Georgia State University, Atlanta.

Gotham, K. F. (2002). Beyond invasion and succession: School segregation, real estate blockbusting, and the political economy of neighborhood racial transition. City \& Community, 1, 83-111.

Grantham, T. C., \& Henfield, M. S. (2011). Black father involvement in gifted education: Thoughts from Black fathers on increasing/improving Black fathergifted teacher partnerships. Gifted Child Today, 34, 47-53.

Green, C. L., Walker, J. M. T., Hoover-Dempsey, K. V., \& Sandler, H. M. (2007). Parents' motivations for involvement in children's education: An empirical test of a theoretical model of parental involvement. Journal of Educational Psychology, 99, 532-544.

Gutman, L. M., \& McLoyd, V. C. (2000). Parents’ management of their children’s education within the home, at school, and in the community: An examination of African-American families living in poverty. Urban Review, 32, 1-24.

Harper, S. R. (2012). Black male student success in higher education: A report from the national Black male college achievement study. Philadelphia: Center for the Study of Race and Equity in Education, University of Pennsylvania.

Harris, C. I. (1993). Whiteness as property. Harvard Law Review, 106, 1707-1791.

Hoover-Dempsey, K. V., Walker Joan, M. T., Sandler Howard, M., Whetsel, D., Green Christa, L., Wilkins Andrew, S., \& Closson, K. (2005). Why do parents become involved? Research findings and implications. The Elementary School Journal, 106, 105-130.

Howard, T. C., Flennaugh, T. K., \& Terry, C. L., Sr. (2012). Black males, social imagery, and the disruption of pathological identities: Implications for research and teaching. Educational Foundations, 26, 85-102.

Howard, T. C., \& Reynolds, R. (2008). Examining parent involvement in reversing the underachievement of African American students in middle-class schools. Educational Foundations, 22, 79-98.

Hughes, D., \& Chen, L. (1997). When and what parents tell children about race: An examination of race-related socialization among African American families. Applied Developmental Science, 1, 200-214.

Jeynes, W. H. (2007). The relationship between parental involvement and urban secondary school student academic achievement: A meta-analysis. Urban Education, 42, 82-110. doi:10.1177/0042085906293818 
Khalifa, M. (2012). A re-new-ed paradigm in successful urban school leadership. Educational Administration Quarterly, 48, 424-467. doi:10.1177/ $0013161 X 11432922$

Ladson-Billings, G. (2000). Fighting for our lives: Preparing teachers to teach African American students. Journal of Teacher Education, 51, 206-214. doi:10.1177/ 0022487100051003008

Lareau, A. (2003). Unequal childhoods: Class, race, and family life. Berkeley: University of California Press.

Lareau, A., \& Horvat, E. M. (1999). Moments of social inclusion and exclusion race, class, and cultural capital in family-school relationships. Sociology of Education, 72, 37-53.

Lawson, M. A. (2003). School-family relations in context: Parent and teacher perceptions of parent involvement. Urban Education, 38, 77-133.

Lightfoot, D. (2004). "Some parents just don't care”: Decoding the meanings of parental involvement in urban schools. Urban Education, 39, 91-107.

Lincoln, Y. S., \& Guba, E. G. (1985). Naturalistic inquiry. Beverly Hills, CA: Sage Publications.

Lipman, P. (1997). Restructuring in context: A case study of teacher participation and the dynamics of ideology, race, and power. American Educational Research Journal, 34, 3-37.

López, G. R., Scribner, J. D., \& Mahitivanichcha, K. (2001). Redefining parental involvement: Lessons from high-performing migrant-impacted schools. American Educational Research Journal, 38, 253-288.

Losen, D. J., \& Martinez, T. E. (2013). Out of school \& off track: The overuse of suspensions in American middle and high schools, Los Angeles, CA, The UCLA Center for Civil Rights Remedies at the Civil Rights Project.

Lynn, M., \& Dixson, A. D. (Eds.). (2013). Handbook of critical race theory in education. New York, NY, Routledge.

Machen, S. M., Wilson, J. D., \& Notar, C. E. (2005). Parental involvement in the classroom. Journal of Instructional Psychology, 32, 13-16.

Mandara, J. (2006). The impact of family functioning on African American males' academic achievement: A review and clarification of the empirical literature. Teachers College Record, 108, 206-223.

Mapp, K. L., \& Kuttner, P. J. (2013). Partners in education: A dual capacity-building framework for family-school partnerships. Washington, DC: SEDL: American Institute for Research, U.S. Department of Education, SEDL.

McGee, E. O., \& Martin, D. B. (2011). "You would not believe what I have to go through to prove my intellectual value!” Stereotype management among academically successful Black mathematics and engineering students. American Educational Research Journal, 48, 1347-1389.

McGrady, P. B., \& Reynolds, J. R. (2013). Racial mismatch in the classroom: Beyond Black-White differences. Sociology of Education, 86, 3-17.

McGrath, D. J., \& Kuriloff, P. J. (1999). “They're going to tear the doors off this place": Upper-middle-class parent school involvement and the educational opportunities of other people's children. Educational Policy, 13, 603-629.

Miller, D. B. (1999). Racial socialization and racial identity: Can they promote resiliency for African American adolescents? Adolescence, 34, 493-501. 
Milner, H. R., IV. (2005). Stability and change in U.S. prospective teachers' beliefs and decisions about diversity and learning to teach. Teaching and Teacher Education, 21, 767-786. doi:10.1016/j.tate.2005.05.010

Milner, H. R., IV. (2008). Disrupting deficit notions of difference: Counter-narratives of teachers and community in urban education. Teaching and Teacher Education, 24, 1573-1598. doi:10.1016/j.tate.2008.02.011

Milner, H. R., IV. (2013). Analyzing poverty, learning, and teaching through a critical race theory lens. Review of Research in Education, 37, 1-53. doi:10.3102/0091732x12459720

Moll, L. C., \& Gonzalez, N. (1997). Teachers as social scientists: Learning about culture from household research. In P. M. Hall (Ed.), Race, ethnicity, and multiculturalism: Policy and practice (Vol. 1, pp. 89-114). Hamden, CT: Garland.

Moynihan, D. P. (1965). The Negro family: The case for national action. Washington, DC: U.S. Department of Labor.

Newman, K. S., \& Chin, M. M. (2003). High stakes: Time poverty, testing, and the children of the working poor. Qualitative Sociology, 26, 3-34.

Noël, R. A. (2014). Income and spending patterns among Black households. Beyond the Numbers: Prices \& Spending, 3(24), 1-8.

Noguera, P. A. (2001). Transforming urban schools through investments in the social capital of parents. In S. Saegert, J. P. Thompson, M. R. Warren \& M. Project (Eds.), Social capital and poor communities (pp. 189-212). New York, NY: Russell Sage Foundation.

Noguera, P. A. (2003). Schools, prisons, and social implications of punishment: Rethinking disciplinary practices. Theory Into Practice, 42, 341-350.

Oakes, J. (2008). Grassroots organizing, social movements, and the right to high-quality education. Stanford Journal of Civil Rights \& Civil Liberties, 4, Article 339.

Oakes, J., Rogers, J., \& Lipton, M. (2006). Learning power: Organizing for education and justice. New York, NY: Teachers College Press.

Parsons, C. (2002). Education, exclusion and citizenship. London, England: Routledge.

Pomerantz, E. M., Elizabeth, A. M., \& Scott, D. L. (2007). The how, whom, and why of parents' involvement in children's academic lives: More is not always better. Review of Educational Research, 77, 373-410.

Posey-Maddox, L. (2012). Middle- and upper-middle-class parent action for urban public schools: Promise or paradox? Teachers College Record, 114, 1-43.

Reay, D. (1998). Class work: Mothers' involvement in their children's primary schooling. London, UK, University College London Press.

Shujaa, M. J. (1992). Afrocentric transformation and parental choice in African American independent schools. Journal of Negro Education, 61, 148-159.

Shumow, L., \& Harris, W. (2000). Teachers' thinking about home-school relations in low-income urban communities. The School Community Journal, 10, 9-24.

Siddle Walker, V. (1996). Their highest potential: An African American school community in the segregated South. Chapel Hill: University of North Carolina Press.

Siegel-Hawley, G. (2013). City lines, county lines, color lines: The relationship between school and housing segregation in four southern metro areas. Teachers College Record, 115, 1-45.

Skiba, R. J., Chung, C.-G., Trachok, M., Baker, T. L., Sheya, A., \& Hughes, R. L. (2014). Parsing disciplinary disproportionality: Contributions of infraction, 
student, and school characteristics to out-of-school suspension and expulsion.

American Educational Research Journal, 51, 640-670. doi:10.3102/ 0002831214541670

Solorzano, D. G. (1998). Critical race theory, race and gender microaggressions, and the experience of Chicana and Chicano scholars. International Journal of Qualitative Studies in Education, 11, 121-136.

Sue, D., Capodilupo, C. M., \& Holder, A. M. B. (2008). Racial microaggressions in the life experience of Black Americans. Professional Psychology, 39, 329-336.

Sullivan, A. L., \& Bal, A. (2013). Disproportionality in special education: Effects of individual and school variables on disability risk. Exceptional Children, 79, 475-494.

Thompson, G. L. (2003). What African American parents want educators to know. Westport, CT: Praeger.

Tobin, J. J., Wu, D. Y. H., \& Davidson, D. H. (Writers). (1989). Preschool in three cultures: Japan, China, and the United States [DVD]. New Haven, CT: Yale University Press.

Toldson, I. A., \& Lemmons, B. P. (2013). Social demographics, the school environment, and parenting practices associated with parents' participation in schools and academic success among Black, Hispanic, and White students. Journal of Human Behavior in the Social Environment, 23, 237-255. doi:10.1080/10911359.2013.747407

Vincent, C., Rollock, N., Ball, S., \& Gillborn, D. (2012). Being strategic, being watchful, being determined: Black middle-class parents and schooling. British Journal of Sociology of Education, 33, 337-354.

Vincent, C., Rollock, N., Ball, S., \& Gillborn, D. (2013). Raising middle-class Black children: Parenting priorities, actions and strategies. Sociology, 47, 427-442. doi:10.1177/0038038512454244

Wakefield, D. V. (2012). Students promoted despite test failure. Educational Forum, 76, 344-355.

Walker, E. V. S. (1993). Caswell county training school, 1933-1969: Relationships between community and school. Harvard Educational Review, 63, 161-183.

Warren, C. A. (2015). Conflicts and contradictions: Conceptions of empathy and the work of good-intentioned early career White female teachers. Urban Education, 50, 572-600.

Warren, C. A. (2016). "We learn through our struggles”: Nuancing notions of urban Black male academic preparation for postsecondary success. Teachers College Record, 118(6), 1-38.

Welch, K., \& Payne, A. A. (2010). Racial threat and punitive school discipline. Social Problems, 57, 25-48

Whitehouse, M., \& Colvin, C. (2001). “Reading” families: Deficit discourse and family literacy. Theory Into Practice, 40, 212-219.

Williams, T. T., \& Sánchez, B. (2012). Parental involvement (and uninvolvement) at an inner-city high school. Urban Education, 47, 625-652. doi:10.1177/ 0042085912437794

Yosso, T. (2006). Whose culture has capital? A critical race theory discussion of community cultural wealth. In A. D. Dixson \& C. K. Rousseau (Eds.), Critical race theory in education: All god's children got a song (pp. 167-189). New York, NY: Routledge. 
Author Biographies

Quaylan Allen is an Assistant Professor in the College of Educational Studies at Chapman University. His research focuses on race, class and gender equity in educational policy and practice, Black male educational outcomes, Black masculinities and visual methodologies.

Dr. White-Smith is Professor of Education and Dean of the LaFetra College of Education (LFCE) at the University of La Verne. She is the intellectual force behind a number of university-community partnerships that serve to identify and promote educational environments, policies, and teaching strategies that foster academic achievement for minoritized students. 